\title{
In Her Own Voice: Charmayne D'Souza
}

Fatima Sahrish

Research Scholar

Department of Languages, Integral University

Lucknow, Uttar Pradesh, India

Sahrishfatima786@gmail.com

Dr. Amna Shamim

Assistant Professor

Department of Languages, Integral University

Lucknow, Uttar Pradesh, India

Abstract

The present paper aims to study Charmayne D'Souza's one and only volume of poetry, $A$ Spelling Guide to Woman. Her poetry shows texture of western feminism where she expresses the radical self of a reformist kind with the strong belief of an iconoclast. Poetry is a two-way process for D'Souza. She uses poetry for not only verbalizing 'personal as political' but also for making the public as personal and as a medium to resist codification of patriarchal discourses. Simone de Beauvoir in The Second Sex has stated that each consciousness defines itself as subject by defining the other consciousness as object. A woman is a paragon of oppressed consciousness, an object in the male psyche. Patriarchy controls the lives of women. Germaine Greer, in this context, has said that patriarchy makes 


\section{DOI: https://doi.org/10.24113/ijellh.v8i1.10401}

women eunuch. It castrates women making them deprived of subjection and treat them as a mere object.

Keywords: Education, Gynocriticism, Misandry, Phallogocentrism, Marriage, Patriarchy

"I want to be doing something with the pen since no other means of action in politics are in a woman's power." -Harriet Martneau

( Ray and Kundu, 2005, 4: 280)

Charmayne D'Souza like other post-Independence poets takes issues of female marginality, discrimination of sexes and call for females to be free from the clutches of traditional Indian role of women. The writers through their writing call for a collective revolt against oppression where education plays a pivotal role in bringing about a change in women's position:

Elaine Showalter's Anthropological Intersecting Circles lay down precisely the history of women's writing; how earlier only men's area was active as he dominated in real life ( 'phallocentrism' ) as well as in literature ( 'phallogocentrism' ), whereas, women were mute, and even when they wrote, about the common area; about love, nature, myths and legends, children, food economy, etc., ... with education came awareness that affected the shift from the practice of 'mad woman in the attic' to women entering the creative arena ...it resulted in the reversal of centre-periphery relationship. In post-colonial terms we may say that just as post-colonialism rejects Eurocentric version of Universalism ( that what Europeans thought was universal) feminists reject Phallocentric version of Universalism (that what men thought was universal). 


\section{DOI: https://doi.org/10.24113/ijellh.v8i1.10401}

D'Souza in "Writers, They Say, Have to Live Life Fully" chooses to indulge in an active life and courageously asserts feminist regalia which shows the feminist battle for vindicating a woman's language :

I Would carry on

With the usual bovine business

Of living

That part of life

Given to me

And not writing about. (33-39)

(A Spelling Guide to Woman n.p )

Beauvoir said that woman is the absolute other and femininity is constructed. D'Souza in her poems show that men think of themselves as humans who are uniquely made for public life and that women are made to support male interests. Man has assumed the notion of universal subject and woman has become the object of male consciousness. Women are still kept in an inferior position so she ridicules man by calling him 'The Rational Animal' because men think themselves as rational and women as stupid creatures. :

After all, men are such animals, little thinking that by acting the sacrificial goat, she too comes among the genus of quadrupeds. ( 19-23) 
DOI: https://doi.org/10.24113/ijellh.v8i1.10401

Beauvoir asserts since women have adapted to be in an oppressed state so men presumed that they have a right to keep women suppressed. The poet in "Cattle-front" shows the notion of 'existence precedes essence'. The poem shows that the roles of women are learned from the tender age and the organisation of society is such that it favours male. Marriage has been promoted artificially to such an extent as if the most important role for women is marriage and in order to save it, they must learn the art to endure at any cost :

She must be prepared to attend to the funeral arrangements of her marriage, make the wedding veil her shroud, (27-31)

( "Cattle-front", A Spelling Guide to Woman n.p )

The poet depicts that patriarchy throughout history forces women to involve in domestic work and raising children. Beauvoir argues the same and says that traditional women have always been prevented from working outside and forced to engage in the household chores :

When she woke up

in the morning,

she combed the sunshine

out of her hair,

prepared to fry him

an egg,

for eternity 
DOI: https://doi.org/10.24113/ijellh.v8i1.10401

settling only for a gas ring. ( 4-11)

( "Good Buy", A Spelling Guide to Woman n.p )

According to the poet marriage is a trap where all women become 'victims of patriarchy'. No matter how educated the men in today's society are, they still stick to the traditional notions of wifehood where women are confined within the space of four walls in accordance with male. If she attempts to cross the chalked out lines, it would disturb manwoman relationship. They openly barter their lives for the sake of togetherness thinking that verbalizing emotions would rip their marriage apart. The poet shares the dilemma of modern women rooted in tradition succumbing silently to the male ego knowing the importance of 'sheltering tree of a husband'. "As men learnt to exercise control over women, they extended their authority over other vulnerable groups: thus slavery emerged"

(Geetha, 2015, 51).

Man exerts its animal power over woman's body. Woman feels suffocated in a bond that fails to deliver her physical or emotional gratification. They are told to act like puppets and to conceal their emotions as if they are mere bits of garbage. Women are confined within the space of four walls which gives a sense of claustrophobia. If she attempts to cross the threshold, it would end their relationship.

Beauvoir, in this connection, asserts that men see women's body as an object of consumption In The Second Sex Beauvoir adapts Merleau-Ponty's argument within the Context of gender: 'Woman like man, is her body; but her body is something Other than herself'(SS: 61). This means that woman's experience of embodiment is separated from her transcendence and, in patriarchal society, which has traditionally promoted woman's objectification, she is rewarded for alienating (or reducing) her transcendent subjectivity to her physicality. In 
DOI: https://doi.org/10.24113/ijellh.v8i1.10401

short, patriarchy furthers its aims by encouraging women to experience themselves as docile bodies for male consumption.

( Tidd, 2004, 58 )

D'Souza uses poetry as a medium to resist codification of patriarchal discourses. She ideates the image of females as the home of male violence. Female body is a deathly trap where they are forced to practice either sexual or reproductive roles dictated by patriarchy and she depicts powerfully how women are commodified :

She said - "Look after me well, for upon my body lie mapy sleepers ( 10-11)

...Adam's rib

chewed to bone, to blood, (33-34)

( "When God First Made A Whore", A Spelling Guide to Woman n.p)

For men, women were the paragon of all good and noble. In literature, the contrast of the good and evil was always there; the 'Fair Maiden' having nobility and chastity was always above the evil nature of the dark lady but these two different categories of good and evil were merged later on in the new American woman. D'Souza celebrates what "Echols credited Freeman for expressing radical-libertarian feminists' desire to free women from the constraints of female biology." (Tong, 2006, 50) :

I don't make babies: ( 6)

...It's hard to feel

I'm a woman.

I do none of the things

a woman does. ( 19-22)

( "A Cheap Woman", A Spelling Guide to Woman n.p ) 


\section{DOI: https://doi.org/10.24113/ijellh.v8i1.10401}

Echols suggests that if a woman is biologically female then it does not mean that she is made to flaunt only feminine characteristics rather she can display feminine as well as masculine characteristics at a time. They have their own wish to choose their gender roles at a particular time by mixing or matching them :

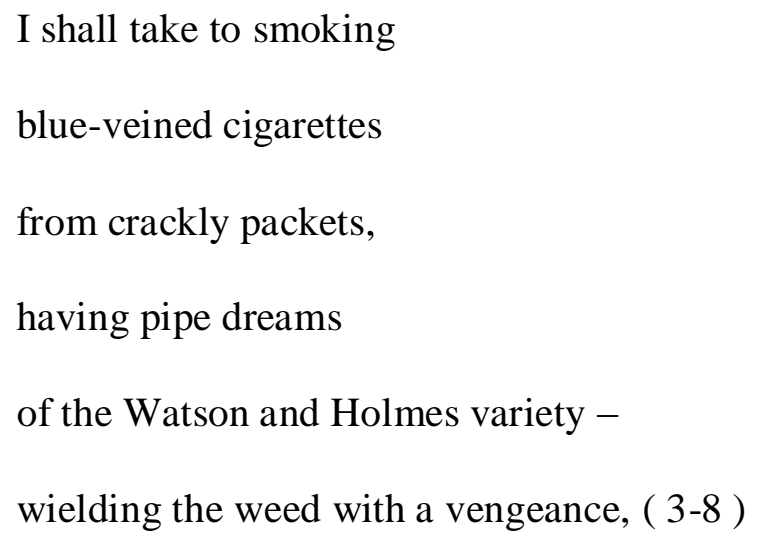

( "Tear-mask", A Spelling Guide to Woman n.p )

Mary Daly emphasized the fact that women would not be able to survive if they continue to live in a patriarchal society. Patriarchy not only twists minds of women but it also ruins women's bodies through such practice like Sati. D'Souza in her several poems rejects 'good' as well as 'bad' aspects of femininity asserted by Daly in Gyn/ Ecology: "I don't drink./ I don't make love... I think I'm a bargain!/ A RESERVED FORCE." ( "A Cheap Woman", A Spelling Guide to Woman n.p ) Those aspects were the 'constructs of patriarchy' used to trap women in the prison so she barters "neither knowledge/ nor light/ to man or God. ( "Star Peace", A Spelling Guide to Woman n.p ). D'Souza seems to strip off her femininity like Daly revealing her originality, the power and beauty of female : "what I am/ is peculiar/ only to me,/ a luxury, I decide,/ to be kept only for myself."

\section{( "A Cheap Woman", A Spelling Guide to Woman n.p ).}

Daly insisted that positive feminine traits such as love, compassion, sharing 
DOI: https://doi.org/10.24113/ijellh.v8i1.10401

and nurturance must be carefully distinguished from their pathological excesses, the sort of masochistic feminine "virtues" for they are frequently mistaken. For example, loving ordinarily is good, but under patriarchy, loving can become, for women, a form of total self-sacrifice or martyrdom. Thus, Daly argued that the construction of the truly androgynous person cannot and must not begin until women say no to the values of the "morality of victimization". Out of this no, said Daly, will come a yes to the values of the "ethics of personhood." By refusing to be the other, by becoming selves with needs, wants, and interests of their own, women will end the game of man as master and woman as slave.

( Tong, 2006, 60)

D'Souza proves to belong to the female tradition, turning to "female experience as a source of an autonomous art, extending the feminist analysis of culture to the forms and techniques of literature" ( Benstock, 2002, 156) "Ellen Moers identified women's writing as a "rapid and powerful" undercurrent beneath the male tradition." ( Benstock, 2002, 156 ) :

My dad tells me to take economics

...I want to take history

...if I take economics,

I will die.

If I take history,

He will, he says. ( 1-17)

( "Coffe Or Me?", A Spelling Guide to Woman n.p )

Being a writer herself, she pens down the role of a writer simultaneously reflecting Showalter's concept of gynocriticism in her poems. D'Souza as a writer, is the producer of textual 


\section{DOI: https://doi.org/10.24113/ijellh.v8i1.10401}

meaning herself and her poems reveal "psychodynamics of female creativity, linguistics and the problem of a female language; the trajectory of the individual or collective female literary career" (qtd. In Benstock, 2002, 158 ). She follows Cixous's saying to re-enter into the world, into the text and into history by their own movement :

Then,

all I would have to do

is write it off as a story,

one that the editor

would not be able to criticize

as shallow, (24-29)

( "Writers, They Say, Have To Live Life Fully", A Spelling Guide to Woman n.p )

The poet manages to free herself from the constraints of patriarchal values so "No familiarity do I wish/ to breed" ( "Tear-mask", A Spelling Guide to Woman n.p ) and by penning down her thoughts she flies free of the patriarchal language telling "That/ is the only thought/ I have" ( "A Cheap Woman", A Spelling Guide to Woman n.p ). She is so confident of her identity that in her life "there will be/ no ifs,/ no butts,/ no stubs." ( "Tear-mask", A Spelling Guide to Woman n.p ). According to her, the false identity - femininity - construct of patriarchy must be stripped away. This only will lead to feel herself as the 'self '. D'Souza does not allow patriarchy to construct, domesticize and tame her :

Do not at a later date

think you have the right

to destroy

what once you put right. ( 20-23)

("The Confidante Trickster", A Spelling Guide to Woman n.p ) 


\section{DOI: https://doi.org/10.24113/ijellh.v8i1.10401}

Women were devoiced and deprived of their tongue which is equal to death or it may be called as the ocean of the unheard or voiceless. Silence is imposed on women by patriarchy telling that silence is golden. To make women voiceless is to dehumanise her. This history of silence is central to history of women. They should break their silence and speak out.

Charmayne D'Souza has de-romanticised husband-wife relationship, showing a sense of misandry. Her poetry has an exquisite imagery that often seems like a social satire and throws light on the discontentment between the sexes. D'Souza refuses to be bound by paternal factors thus making her writing a liberating process. She storms male bastions and has vocalized feminine sensibility making women realize their true identity. She has made the phallocentric world realize that women have their own individuality, uncovering the stereotype gender identity bestowed on them.

Declaration : It is an original work and has not been published or sent for publication anywhere else.

Acknowledgment : Manuscript Communication Number (MCN) : IU / R\& D / 2020MCN000788 
DOI: https://doi.org/10.24113/ijellh.v8i1.10401

\section{Works Cited}

Benstock, Shari, Suzanne Ferris and Susanne Woods. A HANDBOOK OF Literary Feminisms. New York: OUP, 2002.

D'Souza, Charmayne. A Spelling Guide to Woman. New Delhi: Orient Blackswan, 1991.

Geetha, V. Patriarchy. Kolkata: STREE, 2015.

Paul, S.K., Amar Nath Prasad, ed. Indian Poetry in English Roots and Blossoms. 2 vols. New Delhi: Sarup and Sons, 2007.

Ray, Mohit K., Rama Kundu, ed. Studies in Women Writers in English. 5 vols. New Delhi: Atlantic Publishers, 2005.

Tidd, Ursula. Simone de Beauvoir. New York: Routledge, 2004.

Tong, Rosemarie. FEMINIST THOUGHT. Westview Press, 2009. 